\title{
REFINED MAPPING OF EIGHT COSMID MARKERS ON HUMAN CHROMOSOME 22
}

\author{
Hiroki Kurahashi, ${ }^{1,2}$ Kenzo AKaGl, ${ }^{1}$ Ikuo Yana, ${ }^{1}$ \\ Thomas Melot, ${ }^{3}$ Olivier Delattre, ${ }^{3}$ Gilles Thomas, ${ }^{3}$ \\ Shintaro OKADA, ${ }^{2}$ Shin-ichiro TAKaI, ${ }^{1}$ and Isamu Nishisho ${ }^{1, *}$ \\ ${ }^{1}$ Division of Clinical Cenetics, Department of Medical Genetics, Biomedical Research Center, \\ and ${ }^{2}$ Department of Pediatrics, Osaka University Medical School, \\ 2-2 Yamadaoka, Suita, Osaka 565, Japan \\ ${ }^{3}$ Laboratoire de Gènètique des Tumeurs, Institut Curie, \\ 26 rue d'Ulm, 75231 Paris, France
}

\begin{abstract}
Summary Eight cosmid clones were regionally assigned to small subregions of chromosome 22 by hybridization with a total of 22 somatic cell hybrids. One cosmid was localized to the proximal part of $22 \mathrm{q}$ which contained the region commonly deleted in the DiGeorge syndrome. Seven cosmids showing restriction fragment length polymorphisms were localized to the telomeric region distal to the MB locus, which was reported to be frequently deleted in sporadic meningioma. These cosmids, when finely mapped and ordered, are considered useful for the identification of genetic alterations on this chromosome arm.
\end{abstract}

Key Words . DNA marker, chromosome 22, gene mapping, hybrid cell, DiGeorge syndrome

\section{INTRODUCTION}

Chromosome 22, one of the shortest chromosomes among human genomes, is thought to contain several genes responsible for tumorigenic disorders or congenital malformation syndromes. Loss of heterozygosity (LOH) on $22 \mathrm{q}$ has been reported in meningiomas, colorectal cancers, pheochromocytomas, and breast cancers, indicating the possible existence of tumor suppressor(s) on the chromosome arm (Dumanski et al., 1987; Okamoto et al., 1988; Tanaka et al., 1992; Shin et al., 1993; Chen et al., 1991). Moreover, in the case of the DiGeorge syndrome (DGS), deletion of a certain region of $22 \mathrm{q} 11$ is thought to be closely related with

Received January 17, 1994; Revised version accepted April 4, 1994.

* To whom correspondence should be addressed. 
this disease (Driscoll et al., 1992). A previous report of ours described how a total of 108 cosmid markers on human chromosome 22 were newly isolated and roughly mapped with five somatic cell hybrids into four different regions of chromosome 22 (Kurahashi et al., 1994). Of these, 64 detected restriction fragment length polymorphism (RFLP) systems that should be very useful for linkage mapping of the chromosome and for detection of LOH in several human tumors. In this study, eight of the 108 cosmid clones, including seven RFLP markers, were selected for the usefulness of their location and were localized to small subregions by mapping on a panel of 22 rodent/human somatic cell hybrids containing a veriety of partial segment of human chromosome 22.

\section{MATERIALS AND METHODS}

Of 108 cosmids on chromosome 22, eight cosmids, seven of which had been roughly mapped on 22q12.1-qter and one to 22pter-q11.2, were selected (Kurahashi et al., 1994). A total of 22 rodent/human somatic cell hybrids were used for the mapping procedure, most of which had been developed by fusion of human cell lines, each carrying a different chromosome 22 translocation, with a Chinese hamster ovary cell line deficient in adenylosuccinate lyase activity (Delattre et al., 1991). References for the origin of the other hybrids are as follows: $X / 22-33-11 \mathrm{TG}$, 1/22AM27 (Geurts van Kessel et al., 1980); CERCH-h, -s (Hors-Cayla et al., 1981); WESP2A (de Klein et al., 1982); KAG, DAG (Boyd et al., 1988); NF13 (Ledbetter et al., 1989).

Southern hybridization was performed with these cosmids as probes to a panel of the 22 hybrids. High molecular weight DNAs were completely digested with HindIII, separated on agarose gel, and then blotted onto nylon membranes. Cosmid DNA was radiolabeled with $\left[\alpha_{-}{ }^{32} \mathrm{P}\right] \mathrm{dCTP}$ by means of the random-primer method. The radiolabeled cosmids and the membranes were then prehybridized with $200 \mu \mathrm{g} / \mathrm{ml}$ of sonicated human placental DNA in a hybridization solution at $65^{\circ} \mathrm{C}$ for $24 \mathrm{~h}$ to reduce the background effects of human repetitive sequences. Hybridization was performed overnight at $65^{\circ} \mathrm{C}$ in a solution containing $10 \% \mathrm{SDS}$, $7 \%$ polyethylene glycol 8000 , and $200 \mu \mathrm{g} / \mathrm{ml}$ of human placental DNA. After hybridization, the blots were washed twice at room temperature with $2 \times \mathrm{SSC}$, then twice at $65^{\circ} \mathrm{C}$ with $0.1 \times \mathrm{SSC}$ and $0.1 \% \mathrm{SDS}$ for $15 \mathrm{~min}$ each, and exposed to Kodak XAR films at $-80^{\circ} \mathrm{C}$ for $1-3$ days.

\section{RESULTS}

The panel of rodent/human somatic cell hybrids allowed us to assign eight cosmids to small subregions of chromosome 22. Regional localization of the cosmids is schematically shown in Fig. 1. Interestingly, cHKAD-26 contained 

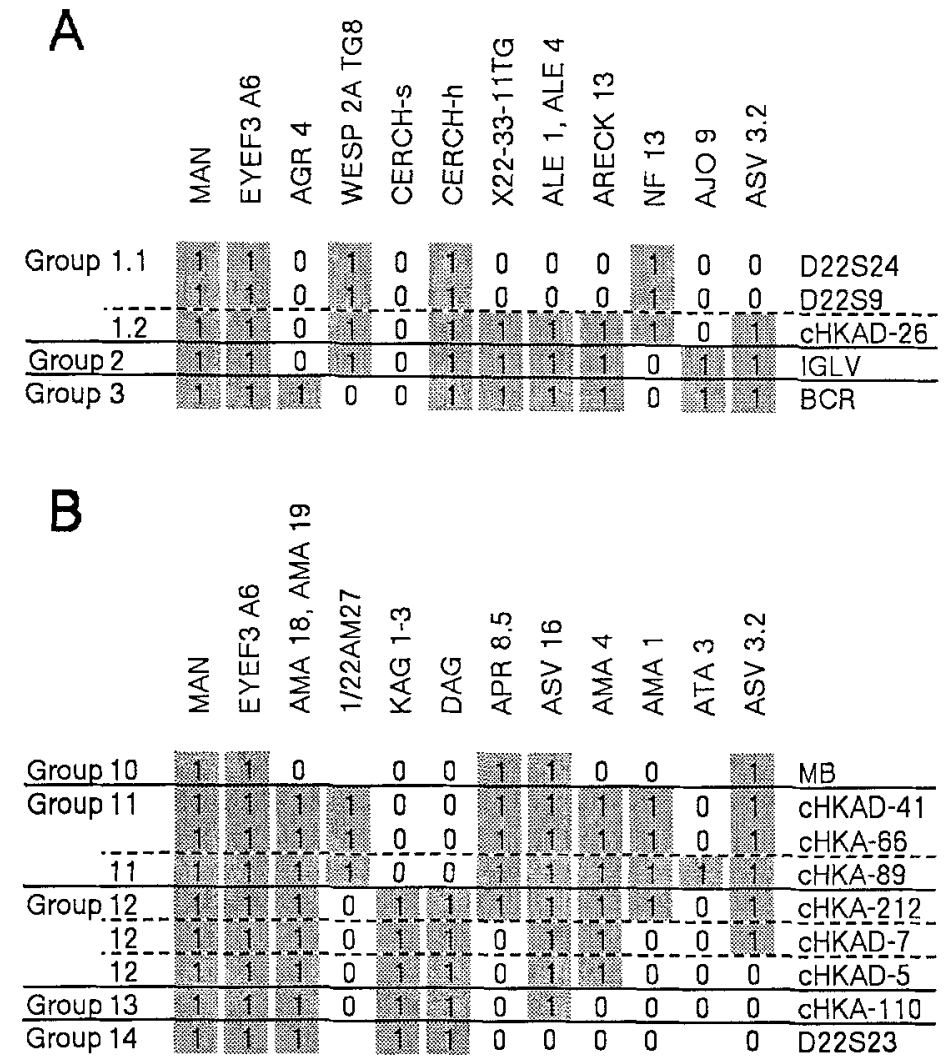

Fig. 1. Mapping of eight cosmids as deduced from the characterization of the panel of somatic cell hybrids. Rectangles indicate the portion of the chromosome 22 present in the hybrids. For a posiitve Southern blot signal, " 1 " is entered, and for a negative one, "0." The name of the hybrids are indicated at the top, while the nem of the cosmid clones are listed on the right. The data for D22S24, D22S9, IGLV, BCR, MB, and D22S23 were derived from the previous study (Delattre et al., 1991). The order in which cHKAD-41, cHKA-66, and cHKA-89 are listed is arbitrary. On the left are indicated the groups that are explained in the reference, and the subgroups that were deduced in this study. A. Mapping of cHKAD-26 near the centromeric region of $22 \mathrm{q}$. P. Mapping of seven polymorphic clones to the telomeric region of $22 q$.

multicopy sequences specific to this small subregion.

Some of the cosmids detected new subregions which had not been defined in the previous report (Delattre et al., 1991): Group 11 could be divided into two and Group 12 into three subregions in this study.

In addition, cHKAD-26, cHKA110, and cHKA212 cross hybridized to mouse and/or Chinese hamster DNAs, indicating that these cosmids contain evolutionarily conserved sequences (data not shown). 


\section{DISCUSSION}

Region-specific DNA fragments have been powerful tools for the investigation of genetic alterations underlying a large number of human diseases. Although a large set of polymorphic or non-polymorphic markers on chromosome 22 has been developed in recent years, additional markers are required for construction of more detailed linkage map of the chromosome. The eight cosmid markers that were finely mapped to small subregions of chromosome 22 should be a valuable source for genetic analysis of the chromosome. In the panel of hybrids used for this study, some of the cosmids detected new subregions which had not been defined in the previous report (Delattre et al., 1991). This panel thus proved to be very useful for mapping procedures to divide chromosome 22 into more refined subregions. Detailed mapping of the remaining cosmids with the aid of the same panel of hybrids is in progress.

DGS is a developmental field defect that involves the third and fourth pharyngeal pouches, causing absence of thymus and parathyroid glands, cardiac conotruncal abnormalities, and facial dysmorphism. A high-resolution banding technique has recently revealed that deletion of $22 \mathrm{q} 11.21-\mathrm{q} 11.23$ is closely related with the syndrome (Wilson et al., 1992). Dosage analysis of cHKAD-26, which had been mapped near the centromeric region of $22 \mathrm{q}$, proved it to be located in the submicroscopically deleted region of two DGS patients (Kurahashi et al., 1994). The present study localized cHKAD-26 within the region between D22S9 and IGLV, where the region commonly deleted in DGS and identified in a previous report lies (Fibson et $a l ., 1990$ ). Therefore, it was physically confirmed that cHKAD-26 locates in the region commonly deleted in DGS. Interestingly, this cosmid contains unique sequences cross-hybridizing to rodent DNAs and multi-copy sequences specific to this small subregion of chromosome 22 (data not shown). A detailed analysis of the locus, including cosmid walking and cDNA isolation, is now in progress.

LOH on $22 \mathrm{q}$ is frequently observed in meningioma, pheochromocytoma, colorectal cancet, and breat cancer. Although the neurofibromatosis 2 (NF2) gene has recently been isolated (Trofatter et al., 1993; Rouleau et al., 1993), there still remains the possibility that additional tumor suppressors associated with development of these tumors exist on the chromosome. Seven clones that were able to detect RFLPs were finely mapped and ordered in the telomeric region of $22 \mathrm{q}$ distal to the MB locus, which was reported to be frequently deleted in sporadic meningioma. A recent investigation of ours showed that several cases of sporadic meningioma had lost the distal part of $22 \mathrm{q}$, while $\mathrm{LOH}$ was more frequently observed in the telomeric region of $22 q$ in colorectal cancer (unpublished data), indicating that other tumor suppressor gene(s) than the NF2 gene may exist in this chromosomal region. The cosmids used in this study should aid the construction of a deletion map to localize the tumor suppressor gene(s) responsible for colorectal cancer and/ 
or sporadic meningioma.

Acknowledgments This work was supported by Grants-in-Aid for Scientific Research and Cancer Research from the Ministry of Education, Science and Culture of Japan and by the CIBA-GEIGY Foundation (Japan) for the Promotion of Science.

Note added in proof. The cosmid markers obtained in this study have been submitted to the Japanese Cancer Research Resources Bank (National Institute of Health, 23-1, Toyama, 1-chome, Shinjuku-ku, Tokyo 162, Japan) and will be available upon request.

\section{REFERENCES}

Boyd Y, Cockburn D, Holt S, Munro E, van Ommen GJ, Gillard B, Affara N, Ferguson-Smith M, Craig I (1988): Mapping of 12 translocation breakpoints in the Xp21 region with respect to the locus for Duchenne muscular dystrophy. Cytogenet Cell Genet 48: 28-34

Chen LC, Kurisu W, Ngo J, Moore D, Smith HS (1991): Loss of heterozygosity on chromosome $18 p$ and 22q in primary breast carcinomas. Proc Am Assoc Cancer Res 32: 300

Delattre O, Azambuja CJ, Aurias A, Zucman J, Peter M, Zhang F, Hors-Cayla MC, Roulear G, Thomas G (1991): Mapping of human chromosome 22 with a panel of somatic cell hybrids. Genomics 9: 721-727

Driscoll DA, Budarf ML, Emanuel BS (1992): A genetic etiology for DiGeorge syndrome: consistent deletions and microdeletions of 22q11. Am J Hum Genet 50: 924-933

Dumanski JP, Carlbom E, Collins VP, Nordenskjold M (1987): Deletion mapping of a locus on human chromosome 22 involved in the oncogenesis of meningioma. Proc Natl Acad Sci USA 84: $9275-9279$

Fibson WJ, Budarf M, McDermid H, Greenberg F, Emanuel BS (1990): Molecular studies of DiGeorge syndrome. Am J Hum Genet 46: 888-895

Geurts van Kessel AHM, Westerveld A, de Groot PG, Meera KP, Hagemeijer A (1980): Regional localization of the genes coding for human ACO2, ARSA, and NAGA on chromosome 22. Cytogenet Cell Genet 28: 169-172

Hors-Cayla MC, Junien C, Heuertz S, Mattei JF, Frézal J (1981): Regional assignment of arysulfatase $\mathrm{A}$, mitochondrial aconitase and $\mathrm{NADH}$-cytochrome $b_{5}$ reductase by somatic cell hybridization. Hum Genet 58: 140-143

de Klein A, Geuerts van Kessel A, Grosveld G, Bartram CR, Hagemeijer A, Bootsma D, Spurr NK, Heisterkamp N, Groffen J, Stephenson JR (1982): A cellular oncogene is translocated to the Philadelphia chromosome in chronic myelocytic leukaemia. Nature 300: 765-767

Kurahashi H, Akagi K, Karakawa K, Nakamura T, Dumanski JP, Sano T, Okada S, Takai S, Nishisho I (1994): Isolation and mapping of cosmid markers on human chromosome 22, including one within the submicroscopically deleted region of DiGeorge syndrome. Hum Genet 93: $248-254$

Ledbetter DH, Rich DC, O'Connel1 P, Leppert M, Carey JC (1989): Precise licalization of NF1 to $17 \mathrm{q} 11.2$ by balanced translocation. Am J Hum Genet 44: 20-24

Okamoto M, Sasaki M, Sugio K, Sato C, Jwama T, Ikeuchi T, Tonomura A, Sasazuki T, Miyaki M (1988): Loss of constitutional heterozygosity in colon carcinoma from patients with familial polyposis coli. Nature 331 : 273-277

Rouleau GA, Merel P, Lutchman M, Sanson M, Zucman J, Marineau C, Hoang-Xuan K, Demczuk S, Desmaze C, Plougastel B, Pulst SM, Lenoir G, Bijlsma E, Fashold R, Dumanski J, de Jong 
P, Parry D, Eldrige R, Aurias A, Delattre O, Thomas G (1993): Alteration in a new gene encoding a putative membrane-organizing protein causes neuro-fibromatosis type 2 . Nature 363: $515-521$

Shin E, Fujita S, Takami K, Kurahashi H, Kurita Y, Kobayashi T, Mori T, Nishisho I, Takai S (1993): Deletion mapping of chromosome $1 \mathrm{p}$ and $22 \mathrm{q}$ in pheochromocytoma. Jpn J Cancer Res 84: 402-408

Tanaka N, Nishisho I, Yamamoto M, Miya A, Shin E, Karakawa K, Fujita S, Kobayashi T, Rouleau G, Mori T, Takai S (1992): Loss of heterozygosity on the long arm of chromosome 22 in pheochromocytoma. Genes Chromosomes Cancer 5: 399-403

Trofatter JA, MacCollin MM, Rutter JL, Murrell JR, Duyao MP, Parry DM, Eldridge R, Kley N, Menon AG, Pulaski K, Haase VH, Ambrose CM, Munroe D, Bove C, Haines JL, Martuza RL, MacDonald ME, Seizinger BR, Short MP, Buckler AJ, Gusella JF (1993): A novel moesin-, ezrin-, radixin-like gene is a candidate for the neurofibromatosis 2 tumor suppressor. Cell 72: $791-800$

Wilson DI, Cross IE, Goodship JA, Brown J, Scambler PJ, Bain HH, Taylor JFN, Walsh K, Bankier A, Burn J, Wolstenholme J (1992): A prospective cytogenetic study of 36 cases of DiGeorge syndrome. Am J Hum Genet 51: 957-963 